\title{
Stereotypical Gender Roles and New Construct of Marriage in Pride and Prejudice
}

\author{
Prof. Taher Badinjki* \\ Dept of English, Faculty of Arts, Al-Zaytoonah University, Amman, Jordan
}

*Corresponding Author: Prof. Taher Badinjki, Dept of English, Faculty of Arts, Al-Zaytoonah University, Amman, Jordan

\begin{abstract}
In Pride and Prejudice, Jane Austen criticizes society's construct of marriage and questions the traditional stereotypical gender roles which considered women as objects and beautiful statues who have no rights. Through the Bennetts, the Collins and the Wickhams she portrays negative models of marriage based on long-established understanding of gender roles and the deire to meet pragmatic social needs. They fall short of of an ideal marriage. On the other side, in the marriage of Elizabeth and Darcy and through the strong independent heroine, she suggests a new model that is built on understanding, love equality and respect.
\end{abstract}

Keywords: Marriage; Stereotypes; Social; Traditional; Gender

\section{INTRODUCTION}

With Jane Austen we move to the closing decades of the $18^{\text {th }}$ century and the early part of the Victorian Era. Social historians and literary critics use the term "Regency" to refer to this period, which is known as the transitional period between the Georgian era and the Victorian era. It was noted for its classiness and achievements in different fields, especially fine arts and architecture. The Regency social conventions and public manners advocated a public appearance of politeness and gentility. The prevailing code of conduct governed every social behaviour and communication, down to the way a woman held or moved her fan to indicate her interest in a gentleman. It was an era in which the social hierarchy was the core of everything and men and women of both sexes knew their place. Women were largely seen as submissive, independent, and passive. They did not inherit wealth, nor were they openly allowed to find their own means. Their role was limited to domestic duties. They were expected to sew, sing, dance, write, read and play music. Women's bodies were seen as something pure. They were not allowed to wear any kind of cosmetics or make-up that would make them look prettier or more attractive, neither were they allowed to wear clothes that would show their skin because society regarded woman as a possession of her husband and she was not allowed to mention words which have a sexual connotation in the presence of men. They were prevented from pursuing education or academic studies because education was another tool which gave individuals a sense of independence and self-confidence. Men are superior, women inferior. It is this mentality which led to the creation of a male-dominated society. Their identity and their fate "were defined and controlled by men - fathers, husbands, or seducers" (Young, 119). Women are tamed and domesticated by men and society. First, it is her "father that controls her fate until she gets married and then it is her husband that controls her fate until she dies" (Mujis, 13).

Marriage was seen as the only option a young woman had in order to secure a comfortable future. In her study of Georgette Heyer's Regency World, Jennifer Kloester (2005) says that "A woman of the Regency period had no other occupation than to find a husband" (72). Income was the first consideration in any offer of marriage. The dowry of a woman was the most important factor and wealthy young men sought to marry women with substantial dowries. Many young women were ready to just marry wealthy upper-class men who would secure them a happy life with money and a comfortable home. Though in their inner circles, many women claimed it was wrong to marry for money, practically, they acknowledged it was silly to marry without it.

To marry and get settled, young unmarried girls had to make themselves desirable in the marriage 
market. Their only hope was a good marriage. In Some Reflections Upon Marriage, Mary Astell (1984), an early English feminist, wrote:

What poor woman is ever taught that she should have a higher design that to get her a husband? Heaven will fall in of course; and if she makes but an obedient and dutiful wife, she cannot miss of it. A husband indeed is thought by both sexes so very valuable, that scarce a man who can keep himself clean and makes a bow, but thinks he is good enough to pretend to any woman, no matter for the difference of birth or fortune, a husband is such a wonder-working name as to make an equality, or something more, whatever it is pronounced. (62-3).

Conduct books and manuals which tell young unmarried girls what to do to catch a socially approved male started to appear and were read by young girls of the time. James S. Fordyce's Sermons to Young Women (1809) stressed the accepted feminine manner of speech, action, and appearance, and Thomas Gisborne's Enquiry into the Duties of the Female Sex (1801), elucidated the specific notions of female identity and provided deeper insights into the ideological concept of womanhood (9-38).

\section{DISCUSSION}

Jane Austen seems to have been acquainted with these manuals, and when we read her novels, we notice how the portrayal of female identity conforms to that description in these books. Her novels reflect the ideological concept of womanhood and the prevailing notions of marriage.

In Pride and Prejudice (1813), she portrays women's dependence on marriage for social security. Notions of womanhood in her works were derived from her culture and her contemporaries. All her women are portrayed as pious, pure, submissive, and dependent on men in their lives. The maximum goal for a woman was to marry a wealthy man in order to have a comfortable life because they did not have other options. She starts the book with a broad statement which says "[i]t is a truth universally acknowledged, that a single man in possession of a good fortune, must be in want of a wife" (Austen, 1). Indeed, this truth, as the novel later shows, seems to be universally acknowledged more by mothers and their eligible daughters than by single men. If a young man appears in the neighbourhood, he becomes the lawful property of any young lady in the area. At the beginning of the book, Mrs Bennet is preoccupied with the idea of marrying her daughters off to wealthy young gentlemen with social status. She asks her husband, Mr Bennet, to visit their new neighbour, Mr Blingly who has just moved in - in this way - he will visit them in return and see their daughters. Mr Bennet was not very much different from his wife in the sense that he wanted to free his daughters from the restrictions of the time by marrying them. He "shares his wife's concern to find husbands for their daughters, since the girls are without fortune or security, and marriage is the only hope for their future" (Wilson, 1985: 53).

The novel explores Austen's intentions through introducing different models of marriages as economical arrangements where women do not have a chance to decide for themselves. She shows how the ladies were in need of rich men. She criticizes society's construct of marriage and questions the stereotypical gender roles which considered women as objects and beautiful statues who have no rights. Woman's place was at home, and her sole duty was to serve and please her husband. The ultimate goal of almost every unmarried girl was to find a husband and get the approval of society. Women had to go through many obstacles to achieve their goals. She portrays negative models of marriage and gives a new model that is built on understanding, love and respect.

In the marriage of Elizabeth and Darcy, Austen portrays an opposite picture of the established norms. She tries to convey the message that individuals should take decisions without taking into consideration society' construct and conventional attitudes. She criticizes the current practices and assumptions of marriage in her society without undermining the ideal of marriage itself. Marriage is not only the result of mutual love and affection between man and the woman, but also a means to achieving social security and respectability. This is shown through the love relationship of Elizabeth and Darcy, negatively stressed by the behaviour of Mr Collins, who proposes to different ladies during his visit to the Bennets. Jane Austen criticizes Mr Collins and those who follow his example.

Mr Collins represents an example of the Victorian who tries hard to satisfy the traditions of that era. For him, marriage is based on convenience and practicality. He wants to marry simply because the rich and pompous Lady Catherine de Bourgh, Darcy's aunt, has employed him as a clergyman. She demands him to marry someone to give a good example to the small Parish he was leading. Collins's 
marriage proposal is made to fulfil two necessities of the time, namely social stability and financial security. His choice of wife switches from Jane to Elizabeth to Charlotte within the course of a few days. This clearly shows that finding a wife is more important than who that wife is. He wants an "angel in the house" to perform the necessary domestic and wifely duties. Mr Collins's view of marriage conforms fully to typical gender roles, as he values a wife not for her own character but for her ability to meet his needs. Mrs Bennet is upset and urges her daughter to accept because Collins will inherit her husband.

Austen presents Collin's engagement to Charlotte as the biggest disaster for Mrs Bennet. If Collins marries Charlotte, she will become the lady of the estate in which they live. Mrs Bennet thinks that Elizabeth is the root of the problem, they are going to lose the house because of Elizabeth's refusal to marry Collins. Her pragmatic view of marriage as nothing more than a contractual relationship is most clearly demonstrated through her attempt to force Elizabeth to marry Mr. Collins, but it seems the same motives led to her own marriage to Mr. Bennett.

Collins is not discouraged by Elizabeth's refusal. He starts to pay attention to Charlotte Lucas. Charlotte, who is Elizabeth's friend, is the first irony of the situation on the theme of marriage in the novel. Because of her age, nobody thinks that she can find a husband, but she turns to be the first to get married. She justifies her decision by stating that "I ask only a comfortable home" (Austen, 115). It would seem that she only cares for materialistic things. Charlotte's "justification correlates with the 19th century notion" that "many women wanted to marry in order to get away from their parental homes" (Blom, 2015:14) In a few hours, he thinks that she is a proper wife for him. She displays a conventional view of marriage based on the traditional gender roles in valuing a husband simply for his ability to provide.

Charlotte is willing to marry Mr. Collins, knowing well that he does not love her and she could never love him. She explains to Elizabeth her decision to marry stating

I am not romantic, you know, I never was. I ask only a comfortable home; and considering Mr. Collin's character, connections, and situation in life, I am convinced that my chance of happiness with him is as fair as most people can boast on entering the marriage state (Austen, 115).

Like Mrs. Bennett, Charlotte sees marriage as a contractual relationship necessary for women to have a place in life and financial security.

The Bennets and the Collins are not the only advertisements of matrimony based on the traditional understanding of gender roles and fall short of perfection. The Wickham's marriage is one more type of marriage that is not desirable. Mr Wickham first proposes to Elizabeth because he thought that her family might have a sum of money. Later on, he runs with Lydia. Mrs Gardiner hears that Elizabeth is attached to Mr Wickham, so she thinks that she needs to warn Elizabeth that Wickham does not have enough money to support a wife. She thinks that he is not suitable for Elizabeth. Mrs Gardiner advises Elizabeth to use her mind "you must not let your fancy run away with you. You have sense" (Austen, 132). Wickham views women as inferior and easily manipulated. When he knows that there is a lady who has inherited ten thousand pounds in town, he goes up to her asking for her hand in marriage. $\mathrm{Mr}$ Wickham is thus revealed as a mercenary, "The sudden acquisition of ten thousand pounds was the most remarkable charm of the young lady to whom he was now rendering himself agreeable" (Austen, 136).

Wickham does not love Lydia and his relationship with her is based on selfish desires. His elopement with Lydia is prompted by money. He does not want to leave his debts behind, so he wants Lydia as a companion to join him in his escape. Mr Bennet gladly acquiesces, deciding that marriage to a scoundrel is better than a ruined reputation. Lydia seems to be stupid, naive, and simple minded. She also does not understand anything about life, She is only interested in getting married, although she knows nothing about this matter. After she elopes with Wickham and he is paid to marry her, she shows no remorse for the embarrassment that her actions cause for her family, but acts as if she has made a wonderful match that her sisters should be jealous of.

Through Lydia, Austen gives us an insight about women who want to attain the recognition that comes from marriage. She is thrilled to be married so young and before her older sisters She is happy that she could catch a husband, although she cannot see marriage as a social institution "I am sure my 
sisters must all envy me. I only hope they may have half my good luck" (Austen, 284). This way of thinking is due to the way she was brought up in such a society that makes marriage the ultimate goal of young unmarried girls.

The elopement of a Victorian lady with a gentleman was a scandalous event in that era because the English civilization was male-centered, so men could have affairs and could do anything they wanted. However, if a girl acted like Lydia did, that would bring bad consequences to her family. This brings stigma to all members of the family, even if the elopement is done for the sake of achieving society's biggest purpose, marriage. Lydia seeks freedom and excitement, but Austen does not give the characters of her novel freedom to be involved in a relationship outside the frame of marriage because she does not want to break out the traditions of society. She criticizes the prevailing assumptions about marriage, but she does not radically break with social conventions. She does not undermine the ideal of matrimony itself, rather she criticizes the current practices and understanding of marriage in her society.

In contrast to these marriages which limit women's freedom and fail to promote a happy and healthy marriage, Austen presents a new ideal in the marriage of Elizabeth and Darcy. Elizabeth's understanding of marriage is not trapped within the current assumptions. She does not view women as inferior and dependent on a husband; consequently, she does not experience the same strain to marry as Charlotte does, despite Mrs. Bennett's urgings. She rejects Mr. Collins's marriage proposal and criticizes Charlotte's view of marriage for she had always felt that "Charlotte's opinion of matrimony was not exactly like her own, but she could not have supposed it possible that when called into action, she would have sacrificed every better feeling to worldly advantage" (Austen, 116).

Elizabeth sees that neither marriage for security, nor marriage based on physical attraction alone, can hold out any possibility of success. She shows no respect for the old aristocratic conventions, represented by Lady Catherine de Bourgh, where by marriage are arranged, not with regard to the individuals involved, but for the sake of promoting the material prosperity of their families. (Wilson, 54) The existence of severe differences between the social classes was presented very openly and clearly in the novel. This idea is made clear while Mr Darcy considers himself an upper class young man, he does not want to dance with a lower class girl. This is actually the inciting force in the novel. So, his pride provokes her prejudice. Even when he was declaring his love and passion for Elizabeth, he stated that he loved her despite the inferiority of her birth and superiority of his rank. Elizabeth refused to marry him despite all restrictions and pressures placed on her, simply because she was a character who was fighting against all these restrictions. Elizabeth refuses to feel shame for being unable to draw, though without fortune or security she turns down advantageous offers of marriage. However, later on she and Mr Darcy come together to fight against all these restrictions and to show the true love is larger than the social classes formed by the Victorians.

She was against the popular image of the ideal wife "The Angel in the house" where the angels were expected to be devoted, submissive to their husbands and they were passive and powerless, therefore, Austen did not marry at all because she could not marry the man she loved. So, Austen encouraged love in her novels, she "portrays Elizabeth Bennet's struggle to express her individuality in a society that demanded strict social conformity.

Through Elizabeth, Austen tries to eliminate harsh treatment for women because she portrays her as one of the most challenging, and rebellious heroine of the nineteenth century female characters. Her strength of character, her intellectual abilities, her sound argument all gone beyond any shadow of doubt that she is a feminist heroine rather than a submissive one. Elizabeth was courageous to reject two marriage proposals and defended her rights as a woman against oppression. Through her, Austen criticizes her society when Elizabeth tries to go against the traditions of society by exploring her emotions through love as Young has discussed:

Women were not allowed to explore what they were capable of achieving, as they had to act as was expected of them. This can be linked with Austen's character of Elizabeth, as she resists this treatment of women. She wants to explore her emotions and her potential without male control and attempts to do this even though society is slow to accept it. (122)

\section{CONCLUSION}

Through the Bennetts, the Collins and the Wickhams, Jane Austen criticizes society's construct of marriage and questions the negative stereotypical gender roles which considered women as objects 
and beautiful statue who have no rights. She shows us traditional models of marriage that are a based on long=established understanding of gender roles and the desire to meet social needs. They fall short of an ideal marriage.

In the marriage of Elizabeth and Darcy, Austen portrays an opposite picture of the established norms and portrays a new model that is built on understanding, love and respect. She shows how love can win even if it goes through many awkward, hard and difficult situations. In other words, there is something that moves the world, despite the rules and prejudices of society.

\section{REFERENCES}

[1] Asteel, Mary. (1984). "Some reflections upon marriage". In Eighteen-century women: An anthology (ed.) Bridget Hill, Oxen, Routledge, London, UK.

[2] Blom, Elin. (2015). Contasting attitudes toward marriage in Pride and Prejudice: Elizabeth Bennet's disregard for the contemporary marital conventions. BA Dissertation, Linnaeus University, Sweden.

[3] Fordyce, James. (1809). Sermons to Young Women, Caret, Philadelphia \& I Riley, New York. USA.

[4] Gisborne, Thomas. (2018). Enquiry into the duties of the female sex. New York:

[5] Jane Austen, (1813). Pride and Prejudice, Republished by Global Grey London, London, 2018. UK. Sububsequent references will appear in the text.

[6] Kloester, Jennifer. (2005). Georgette Heyer's Regency world, London: William Heinmann, UK.

[7] Muji, Arbnore. (2010). Gender issues reflected within nature in Jane Austen's novel Pride and Prejudice. BA dissertation, Linnaeus University, Sweden.

[8] Wilson R. (1985). Themes in Pride and Prejudice by Jane Austen, Macmillan Master Guides. Palgrave, London, UK.

[9] Young, Arlene. (1999). Culture, class and gender in the Victorian novel: Gentlemen, gents and working women. London: Palgrave Macmillan, UK.

\section{AUTHORS' BIOGRAPHY}

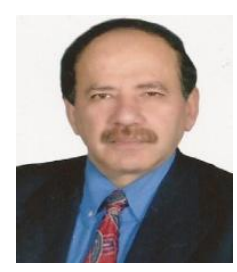

Prof. Taher Badinjki, has an M.Litt from Edinburgh University and $\mathrm{PhD}$ from Glasgow University (UK), and is presently Professor of English Literature at the Dept. of English at Al Zaytoonah University, Amman, Jordan. He is former Professor of English at the Dept. of English Literature, and the Dean of the Faculty of Arts and Humanities at the University of Aleppo in Syria, and at Ittihad University in RAK, United Arab Emirates. He has published and translated a number of books in Lebanon, Syria, the UAE, and Jordan. He has also published research papers in English and in Arabic on English and American Literature, Translation and Arabicization in Kuwait, Syria, USA, UAE and Jordan. Prof. Badinjki is a member of the Borad of Editors and a Reviewer of many international journals of English Literature. He has been working in the field of English Literature, translation and Arabicization for over 25 years. He has taught English Language and Literature at undergraduate and postgraduate levels. He has international work experience in Syria, USA, UAE and Jordan.

Citation: Taher Badinjki. "Stereotypical Gender Roles and New Construct of Marriage in Pride and Prejudice " International Journal on Studies in English Language and Literature (IJSELL), vol 7, no. 1, 2019, pp. 43-47. doi: http://dx.doi.org/10.20431/2347 -3134.0701005.

Copyright: (C) 2019 Authors. This is an open-access article distributed under the terms of the Creative Commons Attribution License, which permits unrestricted use, distribution, and reproduction in any medium, provided the original author and source are credited. 